\title{
American Studies in Hungary
}

\section{(2) OpenEdition \\ Journals}

Electronic version

URL: https://journals.openedition.org/ejas/451

DOI: 10.4000/ejas.451

ISSN: 1991-9336

Publisher

European Association for American Studies

\section{Electronic reference}

Éva Federmayer, "American Studies in Hungary", European journal of American studies [Online], 1-1 I 2006, document 9, Online since 11 January 2006, connection on 10 July 2021. URL: http:// journals.openedition.org/ejas/451 ; DOI: https://doi.org/10.4000/ejas.451

This text was automatically generated on 10 July 2021

Creative Commons License 


\section{American Studies in Hungary}

1 The beginning of American Studies as an academic discipline at Hungarian colleges and universities is basically coterminous with the watershed years of 1989-1990 when the country made a radical shift from state socialism toward parliamentary democracy and a free economy. ${ }^{1}$ This political and economic about-face, which came hand in hand with the undermining of foundationalist certainties and the generation of new anxieties coincided, more or less, with the radical transformation that American Studies was undergoing between the 1990s and early 2000s. ${ }^{2}$ Shaped by crucial scholarly debates in the US American Studies community since the 1970s, "paradigm dramas" (as diagnosed by Gene Wise in 1979) fomented New American Studies with powerful agendas of pluralization and de-centering-a most challenging project that shows striking resonances with changes in Hungarian society and culture since 1990.

2 However, the apparently easy parallel between paradigm shifts in Hungary on the one hand, and in American Studies scholarship in the US on the other, is misleading. Whereas dominant discourses of New American Studies demonstrate a markedly "leftist" commitment to effect social change by remapping the relationship between culture, power and social identities, ${ }^{3}$ current discourses in the highly charged political arena in Hungary demonstrate a shift toward conservative and/or populist agendas. To be sure, a country's political climate (nowadays saturated with nationalist concerns and economic anxieties, real or generated) should not be confused with the politics of another's scholarly community. What I seek to point out is the range of surprising discontinuities that a Hungarian Americanist is inevitably confronted with today when situating herself vis-à-vis subversive "post-Americanist" narratives about the transnational turn and critical internationalism typically dominating US scholarly dialogue today.

3 Rather than perceiving these discrepancies and discontinuities as frustrating obstacles in the way of internationalizing American Studies in Hungary, certain scholars conceive of them as re-energizing points of departure for getting things done in the profession. As a colleague from the University of Szeged in an Interroads debate suggested about his point of enunciation in the context of International American Studies, he "will always be practicing American Studies by nature from the outside, to be plain, as a Hungarian." ${ }^{4}$ Speaking of positionality, Jane Desmond pursued a similar 
point in another context. She proposed that "our most pressing task at this time is not just to exchange research views on topics of mutual interest like American literature, or racial divisions, or foreign policy, or jazz. Rather, it is to collectively analyze the political and intellectual frameworks in which that work has been produced, along with its current configurations." Indeed, the problematics of "internationalizing" American Studies, as we see it from this end, also seems to involve the task of interrogating the impact and meaning of American Studies as an intellectual import to Hungary, and of coping with the concomitant questions of how the object of study along with its critical dimensions are transformed in our teaching and researching American Studies in the national domain. ${ }^{6}$

4 At this point of juncture it is also important to take a short detour of the European context from our vantage point. As a new member state of the European Union, we can't but try to renegotiate a new positionality (or rather, an array of positions) and self-understanding(s) in the current course of "Europeanization," when the United States seems to become, as John Borneman suggests, "Europe's Other." In an insightful essay invited by editor Virginia Dominguez to open a debate on a new collision course between "Europe" and "America," Borneman claims that "[t]his new form of subjectivity, the 'European,' which looks more fragmented and incoherent the closer one gets to it, is nonetheless increasingly taking definition against the cultural practices of members of a particular other country, the United States." ${ }^{8}$ As he suggests, today, contrary to the decades after World War II, when Americanization largely determined the trajectory of modernization, the conditions of globalization, and the spread of products and cultural values in Europe and elsewhere, Americanization/ Westernization is far from being a concept signifying a concerted Euro-American mission. Since West/Westernization and Europe/Europeanization have long been catchwords of a desirable Hungarian self-confidence and identity, this shift in the configuration of meanings may itself account for some of the increasing uncertaintieseven anxieties-among Hungarians today.

5 For all the tendency of a growing divide between Europe and the US (as American and European participants of the $A E$ debate ascertain), European culture, including Hungarian culture, is unquestionably Americanized. While four years ago my colleague, Tibor Frank's diagnosis about the glaring differences between the fundamental parameters of life in America and Europe might have looked valid, ${ }^{9}$ by 2005 , it is Berndt Ostendorf's assessment that seems to apply to the Hungarian situation (especially, with reference to Hungarian political marketing, celebrity politics, personalized elections, economics, marketing and management strategies, the emerging US undergraduategraduate division, along with the credit system). As he succinctly claims, "[i]ronically, one trajectory of Europeanization is precisely Americanization. Often the US way of doing things becomes the only common denominator that all European partners are prepared to agree on." ${ }^{10}$ Elsewhere, Rob Kroes discusses the same tendency when reflecting on America's national symbols that turned into free-floating signifiers in Europe: "Not only have we cracked American cultural codes and come to read them flawlessly, we have also appropriated these codes. They have become part of our collective imaginary repertoire." 11 Since the young generation, our students themselves, have already been socialized according to this collective imaginary repertoire, it is small wonder that they show great interest in courses attempting to interrogate the imbrications of the local into the international (and vice versa) in their 
own cross-cultural and transnational setting, that is, in their own Hungarian American experiences. ${ }^{12}$

With reference to the history of American Studies in Hungary, let me resort to a brief story stressing the importance of the 1970s. ${ }^{13}$ Hungarian American Studies was represented by increasing Hungarian participation in the activities of EAAS, and as a result, the 1986 EAAS Conference was held in Budapest-the first of its kind in a socialist country. ${ }^{14}$ The Hungarian Association for American Studies (HAAS) was established in 1992 and has been a member association of EAAS since 1994. ${ }^{15}$

7 Since the 1970s, especially since the landmark political changes of 1989-90, the number and focus of scholarly publications (including scholarly series, monographs and university textbooks) indicate a lively pluralization and growing interest in the study of the United States. ${ }^{16}$

8 New American Studies itself, as we know it today, with its dialogic dynamics of critical internationalism, has been one of the tangible benefits of the country's political transformation : removing the Iron Curtain and pulling up the intellectual floodgates caused the sudden influx of most heterogeneous intellectual discourses and cultural and academic enterprises, including the appearance of American Studies professors and books about American Studies scholarship in our universities. Though Hungary had previously been regarded as the 'happiest barracks' of the communist camp in Eastern Europe, where, from the 1970s, the political and intellectual pressure was considerably lessened (making traveling and even studying abroad relatively free compared to other satellite countries), the euphoria evoked by the political, military and intellectual liberation of the country in 1989-1990 is still remembered with nostalgia. Rightly so, since the world has suddenly opened up for us, and the vigorous circulation of new ideas and perspectives, the introduction of issues only tangentially dealt with before, the articulation of (gender, ethnic and racial) sensitivities basically dormant before 1990 , opened a new page in our history.

9 It goes without saying that the project of democratic restructuring was bound to affect higher education, specifically, the institutional and academic hierarchies of universities. Indeed, as politicians-irrespective of their ideological commitments or personal interests-did not cease to repeat it, Hungary was to become a strong, "knowledge-based democracy" fit to take center stage in (East) Central Europe. This noble social project was crucially to hinge on the increased participation of universities and colleges as major sites of knowledge production in shaping the contours of a robustly developing Hungarian society. By 2005, however, at the threshold of a 'new age', a year before Hungarian higher education is expected to operate in harmony with the Bologna Agreement as a proud member of the EU academic community, these optimistic prospects, especially at my home institution, ELTE, seem to be in shambles. Exploring the causes of this fiasco is beyond the scope of this short essay. So let me only tentatively hint at three here: the profound cynicism of politicians in view of prioritizing higher education and research in budgetary decisions, wholesale inadequacy in fiscal policy (within and without the university), and die-hard oldguardism in university management.

10 As regards American Studies scholarship, on the other hand, there were promising signs from the very beginning of a radical breakthrough largely due to committed Hungarian Americanists who wished to take the initiative and establish American Studies departments in two major universities, Eötvös Loránd University (ELTE), 
Budapest (establishing the first American Studies department in 1990) and József Attila University, later the University of Szeged (starting the first American Studies program in the country). ${ }^{17}$ Kossuth Lajos University (later the University of Debrecen) with a traditional commitment to the study of American literature and language since the invaluable academic and publishing activities of the late Professor László Országh, ${ }^{18}$ established a North American department ; so, by the early 1990s, there already were three strong seats of teaching American Studies at three major universities at three different, geographically strategic locations in the country. These universities also offer graduate training in American Studies where students can earn a Ph.D. in American Studies, though typically "doctoral schools" operate under the auspices of "doctoral schools of Literary (or English Literary) Studies." Besides the universities just mentioned, other sites of teaching American Studies as part of English Studies sprang into existence in the cities of Pécs, Veszprém, Eger, Nyíregyháza, and Szombathely. Despite budgetary constraints, considerable efforts have been made at university libraries, especially in Budapest, Debrecen and Szeged, to establish or enlarge American collections.

11 As of today, American Studies has been unacknowledged as a "serious" area of study by the Hungarian Scientific Academy (still a major institution to affect decisions about what is to be considered academically creditable and worthy of scholarly attentionand funds). Yet American Studies departments and programs with integrated and inter- and multidisciplinary courses on the USA have, from the beginning, regarded themselves as major sites of innovative efforts in course design, pedagogy, research, and various scholarly activities. Since the mid-1990s, there have been increasing efforts to map out New American Studies involving its Hungarian reconceptualizations in a Cultural Studies and Comparative/International American Studies perspective. This involved successful attempts at de-centering American Studies from its traditionally assumed 'core' constituted of 'high' literature and (consensus) history in order to embrace new themes of study and research relating to US foreign policy, cognitive linguistics, emigration and ethnic studies, film, visual culture, popular culture, African American literature and culture, multiculturalism, canon debates, as well as new methodologies derived from cultural anthropology, feminism, sociology, and critical multiculturalism. ${ }^{19}$

Given the fact that the majority of Hungarian Americanists were trained in English literature and language/linguistics or history and received no formal education in American Studies, old or new, launching, maintaining and developing integrated programs of American Studies courses initially required considerable effort and meant a highly demanding task with regard to the financial implications of this commitment. (Due to low remunerations, Americanists, like other academics, also took up a secondoftentimes a third-job to make ends meet.) Since sabbaticals are unknown in our system, scholarships and fellowships to the US (ACLS or Rockefeller), Germany (Stuttgart Seminar, JF Kennedy Institute in Berlin), Austria (Salzburg Seminar) and other West European countries were, and still are, the most rewarding ways of promoting research and teaching abroad.

There are Hungarian Americanists who regularly teach at prestigious American and West European universities. By now, a growing number of students can also take advantage of studying in the United States and in Western Europe within the framework of student exchange programs such as Erasmus or the ELTE-Graceland 
College exchange program; private foundations (such as the Kellner, Fulbright, Hungarian-American Enterprise Scholarship Foundations) also offer invaluable support to students who wish to study in the US. Two prestigious foundations that have significantly contributed to the raising of the educational and academic standards in American Studies programs, the Salgo and the Fulbright, also deserve mention here. For seventeen years the Salgo Professorship made it possible for distinguished American scholars to come and teach at ELTE; the Fulbright Foundation is still active in facilitating the exchange of American and Hungarian scholars.

For all the popularity of American Studies departments and programs among liberal arts students, the current restructuring of higher education as part of the Hungarian version of the "Bologna Process" clearly signifies a baneful turn in the career of independent American Studies programs and departments. By 2006 we will have lost hold of the institutional space and growing significance we have fought for and attained since 1990. There are troubling signs of old-style disciplinary rigor gaining the upper hand over independent American Studies programs. Indeed, departments of American Studies seem to be seriously imperiled by agents of re-colonization, i.e., by outmoded "modern philology"-"English" in particular. As a result, there will most probably be no B.A. training in American Studies, but only English Studies with American Studies concentration. At this stage of institutional and curricular restructuring, there seem to be efforts made, however, to save American Studies in the form of American Cultural Studies in three tiers at the M.A. level, involving American Culture with concentration on 1) American Literature, 2) American History and 3) Visual Studies.

15 Among the main grounds of intellectual testing and collaboration in American Studies scholarship are the biannual conferences of the Hungarian Association for American Studies (HAAS, founded in 1992). The latest conference was held last November at Eötvös Loránd University, Budapest, structured around the central theme of "American Studies as Cultural Studies: Theory and Practice" (www.geocities.com/haas_budapest). 20

American Studies essays and books are published by university presses such as JATE Press and the University Press of Debrecen, as well as by certain major mainstream publishers. Pioneering in publishing about US culture was the series, Topics in American Studies, launched by the Department of American Studies, Eötvös Loránd University. ${ }^{21}$ The Institute of English and American Studies at the University of Debrecen publishes the Hungarian Journal of English and American Studies twice a year. HJEAS is an internationally circulated, peer-reviewed journal edited by University of Debrecen Professor, Zoltán Abádi-Nagy.

17 The Hungarian Society for the Study of English (HUSSE) is the second major forum of collaboration and exchange addressing English as well as American Studies issues at biannual conferences held in odd-number years (whereas HAAS holds its biannual conferences in even-number years.)

18 In conclusion, as suggested above, American Studies in Hungary has been a dynamically developing area of study since the 1970s with various research aims and agendas, including a strong affiliation with critical International US Studies. Fostered by the political restructuring of the country, the emergent American Studies programs and departments developed into lively sites of academic experimentation and innovation within the walls of conservative Hungarian academia. What the future holds for us 
depends, in large measure, on how we make use of yet another about-face known as the Bologna Process, which offers the fringe benefit of redefining ourselves as Hungarians in a transnationalizing global world.

\section{NOTES}

1. I want to thank Tibor Frank for his helpful comments on the first draft of this essay.

2. See, for example, Donald Pease, ed., National Identities and Postnational Narratives (1994), Cary Nelson, Dilip Parameshwar Gaonkar, eds., Disciplinarity and Dissent in Cultural Studies (1996), John Carlos Rowe, ed., Post-Nationalist American Studies (2000), Giles Gunn, Beyond Solidarity (2001), Gary Y. Okihiro, The Columbia Guide to Asian American History (2001), Gary Colombo, Robert Cullen, Bonnie Lisle, eds., Rereading America (2001), Donald E. Pease and Robyn Wiegman, eds., The Futures of American Studies (2002), Emory Elliott, Louis Freitas Caton, Jeffrey Rhyne, eds., Aesthetics in a Multicultural Age (2002).

3. Resentment felt over the (un-American) political implications of American Studies with Cultural Studies agendas is also voiced by American scholars. Steven Watts, in the special Cultural Studies issue of American Studies, for example, claims that there lies an enormous gap between New Americanists and the general political sentiments of American society: "In case no one has noticed, since at least 1980, and more probably since 1968, the great bulk of Americans have rejected just about everything the left has proposed and moved steadily to the right" (91). Let me note only in passing here that the reverberations of $9 / 11$ and the US's "war on terrorism" seem to further complicate the picture that was thematized, among others, by the 2004 Working Conference of IFUSS (International Forum for US Studies), "Looking North: Latin American Scholarship on the US and Comparative Perspectives," in Rio de Janeiro. For Watts, see "American Studies and Americans" in American Studies 38/2 (Summer 1997): 87-93.

4. See Bálint Rozsnyai's Response to the discussion, "Internationalizing American Studies: A Non-US Perspective, or A View from Turkey" at http:// crossroads.georgetown.edu/interroads/rozsnyai.html

5. See Jane Desmond, “'Mapping American Studies' Across National Boundaries II: The Politics of 'Politics,' the Politics of Knowledge, and the Limits to Collaboration" in Hungarian Journal of English and American Studies (HJEAS) 7/1 (Spring 2001), 128. The talk was given at an international conference hosted by the Department of American Studies, Eötvös Loránd University, which revolved around the theme of "Theory in American Studies." Besides Jane Desmond, among the distinguished speakers were Virginia R. Dominguez and Donald E. Pease.

6. See, for example, the interpretation of 'America' and American Studies from a Hungarian perspective, in "Dangerous Liaisons: Politics and Epistemology in Post-Cold War American Studies" by Enikő Bollobás in American Quarterly 54/4 (Dec. 2002): 563-579.

7. For the whole debate, see American Ethnologist, 30/4 (2003): 485-503.

8. American Ethnologist, 488. 
9. "The teaching of American Studies in Europe is made particularly difficult by the fact that some of the fundamental parameters of life in America such as time and space are, or seem to be, different when compared to Europe." See "Time and Space in the American Mind," HJEAS, 12

10. Berndt Ostendorf, "Is the United States Europe's Other? Is Europe the United States' Other? Yes and no" in American Ethnologist, 492.

11. Rob Kroes, If You've Seen One, You've Seen the Mall: European and American Mass Culture.

(Urbana: U of Illinois P, 1996), 277.

12. For the syllabus and course material of a research seminar (Cultural Studies Research Seminar: American Culture in Hungary) I am currently conducting on this theme, see

http://seas3.elte.hu/coursematerial/FedermayerEva/index.html

13. Let me refer here to Sarolta (Charlotte) Kretzoi first, who was successfully fighting for the existence of university courses about the USA in a most unfriendly academic and political climate. Her 1976 book, Az amerikai irodalom kezdetei /The Beginnings of American Literature/ meant a new beginning of Hungarian American Studies scholarship in the 1970s. Translating, teaching, popularizing, explicating matters of American interest especially relating to American literature and history were Péter Egri, Tibor Frank, István Géher, Zoltán Abádi-Nagy, Bálint Rozsnyai, Aladár Sarbu, Ferenc Takács, Lehel Vadon, and Zsolt Virágos.

14. See the conference proceedings, The Early Republic: The Making of a Nation, The Making of a Culture. Ed. Steve Ickringill, co-edited by Zoltán Abádi-Nagy and Aladár Sarbu (Free University Press, 1988.)

15. For a summary of the early achievements of Hungarian American Studies as a trailblazer in East Europe, see Tibor Frank and Zoltán Kövecses, "American Studies in Hungary", (European Association for American Studies [EAAS] Newsletter, No. 32, March 1994, p. 5).

16. See the wealth of publications since 1990, including Zoltán Abádi-Nagy, Mai amerikai irodalmi kalauz (Guide to Contemporary American Literature/ (Intera, 1995), László Országh-Zsolt Virágos, Az amerikai irodalom története /History of American Literature/ (Eötvös, 1997), Tamás Magyarics, Az Egyesült Államok külpolitikája /US Foreign Policy/ (Eötvös, 2000), Zsófia Bán, Amerikáner (Magvető, 2000);Zoltán Kövecses, Metaphor: A Practical Introduction (Oxford UP, 2002), Tibor Frank, ed., Discussing Hitler: Advisers of U.S. Diplomacy in Central Europe, 1934-1941 (CEU Press, 2003), and Enikő Bollobás, Az Amerikai irodalom története /History of American Literature/ (Osiris, 2005).

17. See Bálint Rozsnyai, "Twenty Years of American Studies in Szeged, Hungary" at http://primus.arts.uszeged.hu/american/americana/rozsnyai.htm 18. See the memorial albums in honor of Országh László, ed. by Vadon Lehel (Eger, 1993;1994).

19. For courses and activities related to American Studies departments, see a few web sites:

http://seas3.elte.hu/, http://primus.arts.u-szeged.hu/american, http://ieas.arts.unideb.hu/ , http://www.btk.pte.hu/tanszekek/angolirod/.

20. The proceedings of major American Studies conferences in the past were published as Studies in English and American Culture, vol. 4, ed. by Tibor Frank (Eötvös University, 1978); The Origins and Originality of American Culture, ed. by Tibor Frank (Akadémiai Kiadó, 
1984); and High and Low in American Culture (Department of English, ELTE, 1986), ed. by Charlotte Kretzoi.

21. Books appearing in the series published in the 1990s include Voices of Friendship: Linguistic Essays in Honor of András T. László, ed. by Zoltán Kövecses; Values in American Society, ed. by Tibor Frank; New Approaches to American English, ed. by Zoltán Kövecses; Carmen Saeculare: American Philantropy, ed. by Jenő Bárdos.

INDEX

Keywords: film, popular culture, sociology, multiculturalism, Feminism, Emigration, American literature, ethnic studies, cognitive linguistics, cultural anthropology, critical multiculturalism, Bologna Process, American History, Visual Studies., foreign policy, African-American literature and culture 